similar circumstances. In both instances, the birds chose the floor of abandoned barns. ' Most nests are located in caves, hollow logs or dense undergrowth. Houston's summary of breeding locations in Saskatchewan also listed various examples of ground nesting in the 12 areas reported, as did Schmidt. ${ }^{3}$ In conclusion, the vulture breeding record near Biggar appears to be quite unique. The birds did not nest in either locality in 1984. (Norm Smith, pers. comm.)

Turkey Vultures are listed as rare transients in the Rosetown-Biggar district, immediately south of this observation, by Renaud and Renaud. ${ }^{4}$ They listed six records for the species up until 1975. Since then, there have been only two other occasions when vultures have been reported: 14 May 1976, a single adult over Biggar; ${ }^{5} 6$ June 1982, one adult noted by the author, $30 \mathrm{~km}$ west of Biggar.

${ }^{1}$ BENT, A.C. 1961. Life histories of North American birds of prey. Volume 1. Dover Reprint. New York. 409 pp.

${ }^{2}$ HOUSTON, C.S. 1969. Turkey Vulture breeding records in Saskatchewan. Blue Jay 27(1):37-38.

${ }^{3}$ SCHMIDT, J.W. 1973. Cave-nesting Turkey Vultures of the South Saskatchewan. Blue Jay 31(1):58.

${ }^{4}$ RENAUD, W.E. \& D. H. RENAUD. 1975. Birds of the Rosetown-Biggar District, Saskatchewan. S.N.H.S. Special Publication No. 9. 120 pp.

${ }^{5}$ WAPPLE, G.J. 1976. Additions to "Birds of the Rosetown-Biggar District, Saskatchewan". Blue Jay 35(3):157-160.

\title{
ABANDONED HOUSE NEST SITE FOR TURKEY VULTURE
}

RHYS BEAULIEU, Saskatchewan Parks and Renewable Resources, Box 970, Hudson Bay, Saskatchewan. SOE OYO

Part of my job as Regional Wildlife Biologist with Saskatchewan Parks and Renewable Resources is to look into the possibility of improving habitat conditions on Wildlife Development Fund Lands to increase wildlife production. On 15 June 1984 Dan McGill, Conservation Officer at Preeceville, and I were carrying out a habitat investigation on WDF land north of Preeceville, Saskatchewan. A local land owner had contacted McGill about rebreaking and seeding to alfalfa a 15 acre field. The first cut of alfalfa (cut after the nesting season) would be sold to the farmer with the money going back into the Wildlife Development Fund and the second cut would be left stainding to provide an increased food source for White-tailed Dear and Elk and cover for upland game birds, waterfowl and other species of birds and mammals.

Overlooking the field, was a small abandoned two story house which we investigated. The house was a log structure in very poor condition. I 


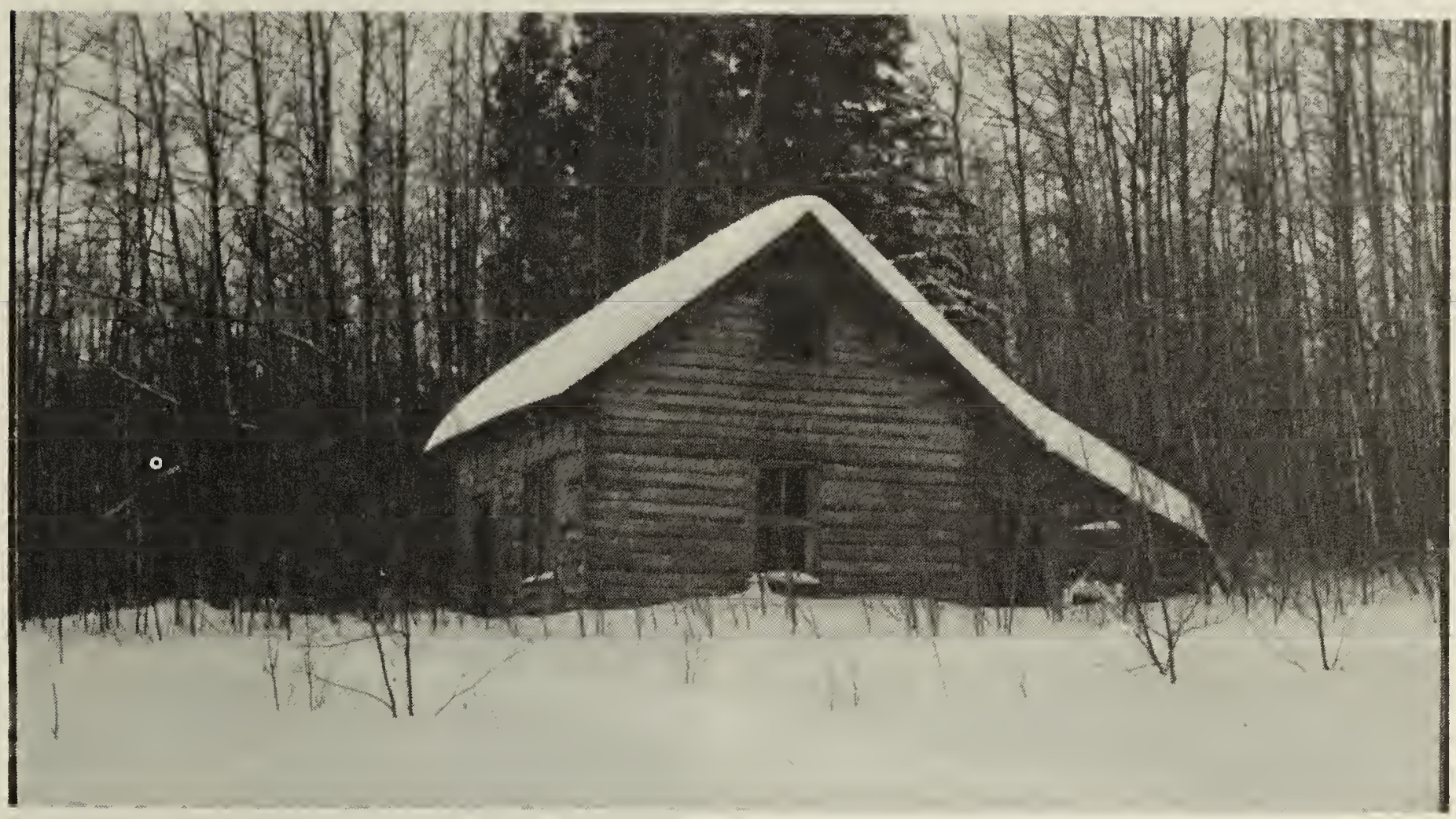

Log house, top window used by Turkey Vulture to enter upper story

Rhys Beaulieu

climbed the steps to the second story and for a couple of seconds, while still standing on the steps, watched a large dark bird walking towards me. The bird quickly took flight through the open window. I was somewhat startled; it took me a few moments to realize that the bird was a Turkey Vulture. Entering the upstairs room, I found two eggs the size of chicken eggs, light brown in colour. There appeared to be no attempt to make a nest since the eggs were on the bare floor about 20 in. from the corner of the room.

On 17 July, 1984 I returned to the house hoping to take pictures of the adult bird and the hatched young. I found only one chick. The adults were either frightened off when I entered the house or were out scavenging for food. The single chick was still covered with down, although there was evidence of flight feathers. It stood about 12 in. high and displayed defence actions which included outstretching its wings and making a hissing sound. Unfortunately there was not enough light for good pictures.

Wenzel Fialkowski, a local farmer, informed me that this is the second year that Turkey Vultures have used the house as a nesting site. Fialkowski said that in 1983 two chicks were raised to the flight stage and previous to my visit he had noted that two young had hatched in 1984. The chicks were very young when he visited the house. One can only guess what happened to the other young. Perhaps the living young outcompeted the other for available food.

Turkey vultures prefer covered nesting sites, which include hollow logs, caves, and at the bottom of cliffs.' In Saskatchewan, where hollow trees are not large enough, nests are usually restricted to brush piles and caves. In the Porcupine Forest area, I am aware of only two other nest records as follows: Mr. Odd Steiestol reported finding two nests in 1980, one in a wood pile in Greenwater Lake Provincial Park and the other in a brush pile along a 
cutline north of Marean Lake. ${ }^{2}$ There has apparently been only one other report of vultures nesting in a house in Saskatchewan. [In this issue.-Ed.]

Wildlife Development Fund Lands are managed for all wildlife. Old buildings, if found to be of value to wildlife, are left stading to provide nesting sites, burrows, and cover for wildlife. The old house north of Preeceville will remain with the hopes of providing a nesting site for Turkey Vultures for many years.

'SALT, W.R. and J.R. SALT 1976. The birds of Alberta. Hurtig Publishers, Edmonton, Alberta

${ }^{2}$ HARRIS, W.C., S.M. LAMONT and C.I.G. ADAM 1984. Greenwater Provincial Park Resouce Inventory and Analysis. Prairie Environmental Services Incorporated, Raymore, Saskatchewan

\section{NORTHERN TURKEY VULTURE NEST}

FRANK SCOTT, Box 190, Loon

Lake, Saskatchewan. SOM 1L0

On 12 August 1984, Brad Tokaruk, a local conservation officer, whilst on a boat patrol of Ministikwin Lake, $\left(54^{\circ}\right.$ $2^{\prime} \mathrm{N}, 109^{\circ} 40^{\prime} \mathrm{W}$ ) saw two young raptors on the shore and went to investigate. The two young scrambled into a cave under a dead tree and hissed at him. No adult birds were seen. On 13 August I accompanied Tokaruk to investigate the site.

As we approached there was an adult vulture soaring over the shoreline. The cave, which was situated about 6 feet back from the water

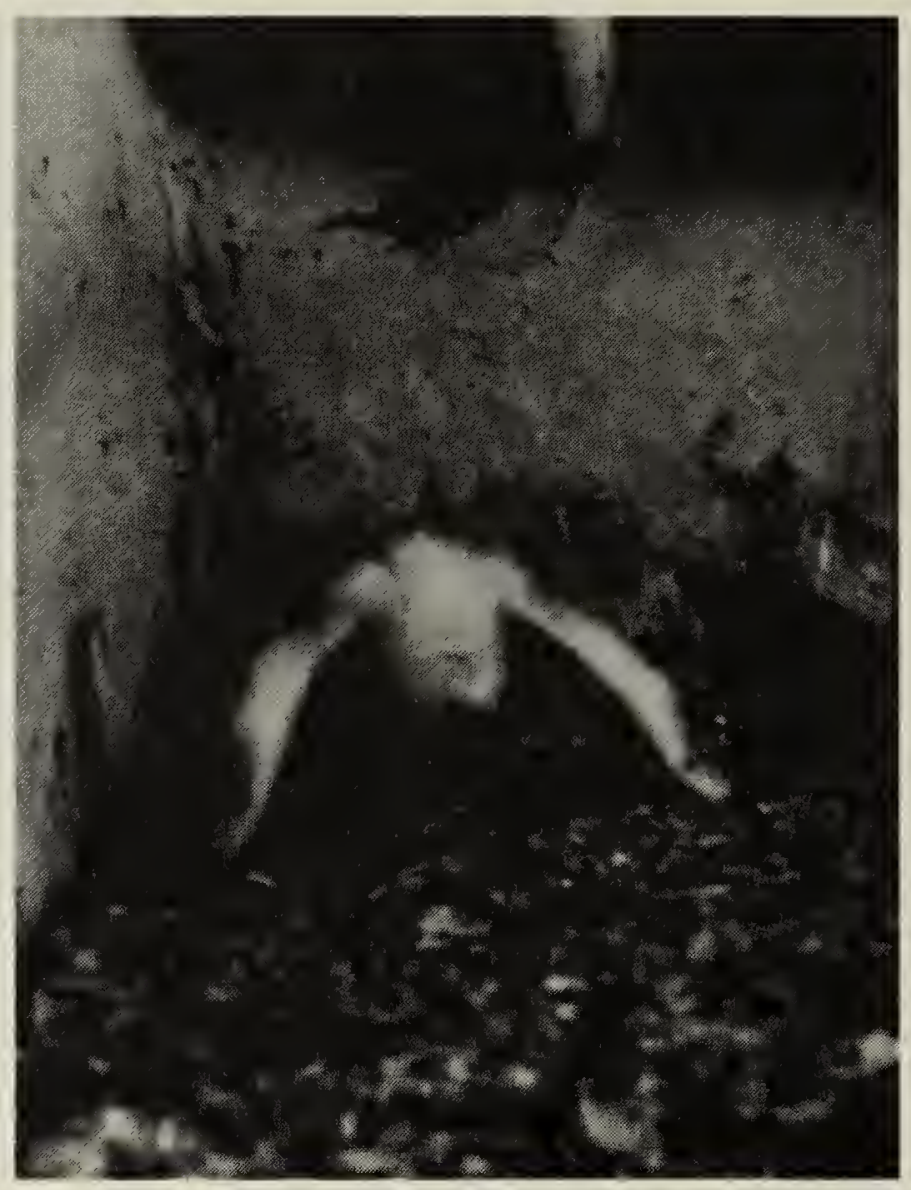

Turkey Vulture young

Rhys Beaulieu

under a dead tree, was approximately $3 \times 3 \mathrm{ft} . \times 9 \mathrm{in}$. high. There was obvious evidence of occupation but no young birds were present at that time. No search was made for them since the bush was dense and wet.

Turkey Vultures are often seen in this area but this is the first nest I have seen, and it would have certainly been overlooked had the young not been right at the water's edge.

A week later the site was revisited and there were three adult and one immature Turkey Vultures sitting in trees near the shore. The young bird could be approached to $10 \mathrm{ft}$. but only poor quality polariod photographs were obtained. No search was made for the second young vulture. 